\title{
The Supreme Court at the Bar of Public Opinion Polls
}

\author{
Or Bassok ${ }^{\bullet}$ \\ [Published in Constellations, volume 23, December 2016, pp. 573-584]
}

\section{Introduction}

Chief Justice Roberts' dissenting opinion in Obergefell v. Hodges ${ }^{1}$ contains two conflicting understandings of the Supreme Court's source of legitimacy. The first, relying on The Federalist No. $78,{ }^{2}$ positions "judgment" as the Court's source of legitimacy; ${ }^{3}$ the second relies on a quote from an earlier judgment in which Justice Kennedy paraphrased The Federalist No. 78 and positions "public respect" as the Court's source of legitimacy. ${ }^{4}$ In this article, I explain how these two readings of The Federalist No. 78 represent two distinct ways of understanding judicial legitimacy. According to the first, stating that the Supreme Court (hereinafter: the Court) has legitimacy means that its authority is justified by its expertise in law or in a related field such as human rights. According to the second, newer

\footnotetext{
- Or Bassok is an Assistant Professor at the Faculty of Law at the University of Nottingham. An earlier version of this article was presented at the 2015 International Society of Public Law (ICON-S) Conference. For insightful comments I am grateful to Jack Balkin, Mark Graber, Miguel Schor, and Catie Scott. This article has been published in final form at http://onlinelibrary.wiley.com/doi/10.1111/1467-8675.12211/abstract. It may be used for noncommercial purposes in accordance with Wiley Terms and Conditions for Self-Archiving.

${ }^{1}$ Obergefell v. Hodges, 135 S. Ct. 2584, 2611 (2015) (Roberts, C.J., dissenting).

2 Alexander Hamilton, "The Federalist No. 78," The Federalist Papers, ed. Ian Shapiro (New Haven: Yale University Press, 2009), 392.

${ }^{3}$ Obergefell, 2611

${ }^{4}$ Obergefell, 2624
} 
understanding, judicial legitimacy means that public opinion polls demonstrate high levels of enduring public support for the Court.

A hundred years ago, it would have been impossible to say that the Court has legitimacy because public opinion polls demonstrate high levels of enduring public support for the Court. This use of the concept of "judicial legitimacy," now very common, ${ }^{5}$ would have been impossible to fathom before the invention of public opinion polls during the 1930s. It would still have been implausible to attribute such a meaning to judicial legitimacy until recent decades, when polling organizations started to measure public support for the Court. The more plausible interpretation, until recently, of the statement that "the Court has legitimacy" was that its authority or its judgments were justified in moral terms in a way that is unrelated to its public support. ${ }^{6}$

Even before the invention of opinion polls, justices and scholars sometimes spoke of the Court's source of legitimacy as emanating from "public confidence."7 Yet, in the absence of public opinion polls, their understanding of public opinion was very different to ours. The argument that I develop below is that public opinion was understood not as a simple aggregate of individual opinions but more as a diffused public state of mind expressed by institutions such as Congress. ${ }^{8}$ In any conflict between the Court and the elected branches, the President and Congress could always rely, based on the most recent elections, on their public

\footnotetext{
${ }^{5}$ For example, Jeffery Rosen argues the Court has a legitimacy problem based on "a New York Times/CBS poll [that] found that only 44 percent of Americans approve of the Supreme Court's job performance." See Jeffery Rosen, "The Supreme Court has a Legitimacy Crisis, But Not for the Reason You Think," The New Republic, June 11, 2012. https://newrepublic.com/article/103987/thesupreme-court-has-legitimacy-crisis-not-the-reason-you-think, accessed January 25, 2015.

6 See Mark Tushnet, "Justification in Constitutional Adjudication: A Comment on Constitutional Interpretation,” Texas Law Review 72 (1994), 1707, 1714.

${ }^{7}$ See Holmes v. Jennison, 39 U.S. 540, 618 (1840) (Baldwin J., concurring).

8 Leo Bogart, Polls and the Awareness of Public Opinion (New Brunswick: NJ, Communication Books, 1985), 14-15; Mark G. Schmeller, "Imagining Public Opinion in Antebellum America: Fear, Credit, Law, and Honor" (Ph.D. diss., University of Chicago, 2001), 3, 11.
} 
support. There was no way for the Court to rely on the tacit understanding, based on published public opinion polls, that it enjoyed public support. Public opinion polls introduced for the first time in history an independent source of evidence, considered reliable by all relevant players, of public support for the Court.

The focus of this article is to explain how the understanding of the concept of judicial legitimacy has changed in American constitutional discourse in recent decades. This change has two ingredients: first, notions of "public confidence" in the Court (or in the scholarly jargon "sociological legitimacy") became synonymous with measurements in public opinion polls; second, the understanding of judicial legitimacy in terms of public confidence, rather than in terms of justifying the Court's work based on moral reasons, has become prevalent.

To demonstrate this change, I begin this article by presenting a comparison between Hamilton's dictum on the judiciary, from The Federalist No. 78, and the way Americans currently paraphrase it. I argue that while Hamilton viewed the judiciary's legitimacy in terms of expertise, today he is paraphrased as if he viewed the judiciary's legitimacy in terms of public support. In the third section, I explain that the invention of public opinion polls created the conditions for this change in the understanding of the concept of judicial legitimacy. At the end of this section, I stress that the change in understanding judicial legitimacy does not mean that courts have to follow public opinion. A court can understand its legitimacy in terms of public support and still follow legal expertise if it believes that such a strategy will be beneficial in terms of public support. I demonstrate my argument by discussing Chief Justice Roberts' recent dissenting opinion in Obergefell $v$. Hodges.

In the fourth section, I discuss the decline in the belief in legal expertise in the USA since the New Deal era. This decline is responsible, in part, for viewing Hamilton's dictum on the source of the Court's legitimacy with disbelief. In order to demonstrate that Hamilton's vision is plausible I explore the example of the Federal Reserve Bank and the example of the South African Constitutional Court (henceforth: SACC) in its first 10 years of existence. Both examples demonstrate that Hamilton's vision of judicial legitimacy based on expertise is both possible and plausible. 
A sentence in Justice Felix Frankfurter's dissenting opinion in Baker v. Carr ${ }^{9}$ is arguably the origin of the paraphrasing of Hamilton. In this sentence, Frankfurter paraphrases Hamilton but replaces "judgment" with "public confidence." Before concluding, I reveal that Frankfurter kept returning to this sentence in his drafts and changing it. I explain that Frankfurter did not identify public confidence in the Court with the result of public opinion polls as we do today.

\section{The Evolution of The Federalist No. 78}

The concept of legitimacy has several faces. One face is normative, another sociological. ${ }^{10}$ In the context of the institutional legitimacy of courts, according to the normative understanding of legitimacy, a court enjoys institutional legitimacy as long as its authority can be normatively justified. For example, one may argue that the Court's authority is justified, and hence that the Court has institutional legitimacy, as long as it adequately protects human rights that are anchored in the Constitution. ${ }^{11}$ According to the sociological understanding of legitimacy, a court enjoys institutional legitimacy as long as the public awards it support over a relatively long period of time. ${ }^{12}$

While these two meanings of legitimacy are connected, the existence of one does not necessarily imply that the other follows. Even if a court's authority is justified (normative legitimacy), it can still lack enduring public support

\footnotetext{
${ }^{9}$ Baker v. Carr 369 U.S. 186, 267 (1962).

${ }^{10}$ See e.g., Richard H. Fallon, Jr., "Legitimacy and the Constitution," Harvard Law Review 118 (2005), 1787.

${ }^{11}$ See Michael J. Perry, "Protecting Human Rights in a Democracy: What Role for Courts," Wake Forest Law Review 38 (2003), 635, 655-7.

12 See James L. Gibson and Gregory A. Caldeira, Citizens, Courts, and Confirmations (Princeton, NJ: Princeton University Press, 2009), 38.
} 
(sociological legitimacy). ${ }^{13}$ The public may have no confidence in a court since it misunderstands the court's judgments, although they can easily be justified according to normative standards. Similarly, saying that a court enjoys enduring public support does not imply that this support is warranted according to normative standards. The public may support a court based on a myth concerning the judges' expert knowledge in solving conflicts of values while in reality judges lack any expertise in resolving such conflicts. ${ }^{14}$ Enduring public support for a court may serve, under certain circumstances, as an independent normative justification for its authority. ${ }^{15}$ But most scholars attempt to justify the Court's authority without resorting to public support, since they view the Court's role in contrasting public opinion on certain occasions to be an essential part of its role in a democratic system of government. ${ }^{16}$

In 1788, Alexander Hamilton famously proclaimed in The Federalist No. 78 that

[t]he judiciary on the contrary has no influence over either the sword or the purse. . . It may truly be said to have neither Force nor Will, but merely judgment; and must ultimately depend upon the aid of the executive arm even for the efficacy of its judgments. ${ }^{17}$

According to Hamilton, the government's support, essential for the efficacy of the Court's rulings, is acquired because the executive branch acknowledges the value of the Court's judgment and not because it is fearful of public reaction. Even if the

13 Or Bassok, "The Sociological-Legitimacy Difficulty," Journal of Law \& Politics 26 (2011), 239, 268-71.

${ }^{14}$ Ibid., 268-70.

15 Or Bassok and Yoav Dotan, "Solving the Countermajoritarian Difficulty?,' International Journal of Constitutional Law 11 (2013), 13.

${ }_{16}$ Mark A. Graber, A New Introduction to American Constitutionalism (New York: Oxford University Press 2013), 104-7.

${ }^{17}$ The Federalist No. 78, 392 (Alexander Hamilton). 
Court makes a judgment that is contrary to popular opinion or to the government's interests, the government will still enforce the judgment, in the same way a patient complies with a treatment that causes her pain. Thus, Hamilton based the Court's power "merely" on its judicial expertise; not on public support for the Court. ${ }^{18}$

Hamilton's position represents well the negative view of popular opinion held by many of the founders. ${ }^{19}$ The electoral college system for electing the President and the election of two senators per state, regardless of the size of the state's population, are two vivid examples of how the founders designed the Constitution to dilute the power of popular will. ${ }^{20}$ The Court is another example. The founders designed the Court to counter shifts in popular opinion that contradicted the Constitution. ${ }^{21}$ In this spirit, Hamilton wrote that "the independence of the judges may be an essential safeguard against the effects of occasional ill humors in the society." 22 According to this line of thinking, expert knowledge is the tool that enables judges to guard the Constitution from public opinion. ${ }^{23}$ This expertise in law is one reason for Hamilton's objection in The Federalist No. 81 that the final appeal in cases will be to the Senate, as the equivalent of the British House of Lords. Hamilton explains that judges as "men selected for their knowledge of the laws, acquired by long and laborious study" are better equipped to ensure that the

${ }^{18}$ See Keith E. Whittington, Constitutional Interpretation: Textual Meaning, Original Intent, and Judicial Review (Lawrence KN: University Press of Kansas, 1999), 54.

${ }^{19}$ See for example, Thomas R. Marshall, Public Opinion and the Supreme Court (Boston: Unwin Hyman, 1989), 1-2; Daniel A. Farber and Suzanna Sherry, Desperately Seeking Certainty: The Misguided Quest for Constitutional Foundations (Chicago, IL: University of Chicago Press, 2002), 86-8.

${ }^{20}$ See Morton J. Horwitz, "The Supreme Court, 1992 Term; Foreword: The Constitution of Change: Legal Fundamentality without Fundamentalism," Harvard Law Review 107 (1993), 30, 589.

${ }^{21}$ Farber and Sherry, Desperately Seeking, 103-4.

${ }^{22}$ The Federalist No. 78, 396.

${ }^{23}$ See Jack N. Rakove, "The Original Justifications for Judicial Independence," Georgetown Law Journal 95 (2007), 1061, 1071. 
Constitution would not be breached than elected representatives. ${ }^{24}$ Thus, recognizing public support as the source of the Court's legitimacy would not make much sense to the founders.

In 2012 Pamela Karlan ends her Harvard Foreword titled "Democracy and Disdain" by saying:

Alexander Hamilton was slightly off base when he wrote that the judiciary has "neither Force nor will but merely judgment; and must ultimately depend upon the aid of the executive arm even for the efficacy of its judgments." The judiciary must ultimately depend on the people. ${ }^{25}$

In other words, Karlan views public support as the Court's source of legitimacy. Even if the Court lacks expertise, as long as it holds public support, it will function properly.

It is not surprising that Karlan views the idea that the Court must have public support to function properly as a truism and suggests that Hamilton got it ("slightly") wrong. The idea of a link between public support for the Court and its ability to function properly has become so powerful in American constitutional discourse that it has become common sense. Most scholars do not even notice, as Karlan did, that they are paraphrasing what Hamilton wrote in The Federalist No. 78 to fit this controlling understanding. They just read Hamilton as confirming the controlling paradigm. For example, in their work "On the Legitimacy of National High Courts," social scientists James Gibson, Gregory Caldeira and Vanessa Baird write that

24 The Federalist No. 81, 408 (Alexander Hamilton). See also Rakove, "The Original Justifications," 1070-71.

${ }^{25}$ Pamela S. Karlan, "The Supreme Court, 2011 Term, Foreword: Democracy and Disdain," Harvard Law Review 126 (2012) 1, 71. 
[n]ot even the most powerful courts in the world have the power of the "purse" or "sword"; with limited institutional resources, courts are therefore uncommonly dependent upon the goodwill of their constituents for both support and compliance ... courts, more than other political institutions, require a deep reservoir of goodwill. ${ }^{26}$

The authors then use public opinion polls to measure that "reservoir of goodwill." In the same spirit, social scientists James Stoutenborough and Donald HaiderMarkel write that

[1] egitimacy is tied, to a great extent, to the public's confidence, or specific support, in the Court as an institution . . . and without a reservoir of goodwill the Court will struggle to maintain its legitimacy. ${ }^{27}$

They then refer both to Frankfurter's sentence from Baker v. Carr noting that "Justice Felix Frankfurter may have best summarized the issue" and to The Federalist No. $78 .^{28}$

For modern American "readers" of Hamilton the crucial question is whether the Court holds sociological legitimacy, that is, whether the public supports it. For Hamilton, the question was whether the Court has "judgment;" whether it holds expertise. This belief in legal expertise was shared by many of the founders. ${ }^{29}$ What was it that happened to shift so dramatically the understanding of the Court's source of legitimacy? The invention of public opinion polling was what happened.

26 James L. Gibson, Gregory A. Caldeira and Vanessa A. Baird, "On the Legitimacy of National High Courts," American Political Science Review 92 (1998), 343, 343. See also Richard Davis, Justices and Journalists (New York: Cambridge University Press, 2011), 19.

${ }^{27}$ James W. Stoutenborough and Donald P. Haider-Markel, "Public Confidence in the U.S. Supreme: A New Look at the Impact of Court Decisions," The Social Science Journal 45 (2008), 28, 29 (citations omitted).

${ }^{28}$ Ibid.

${ }^{29}$ See Rakove, "The Original Justifications," 1068; Bruce Ackerman, The Decline and Fall of the American Republic (Cambridge, MA: Harvard University Press, 2010), 33 


\section{The Effect of the Rise of Public Opinion Polling on Understanding Judicial Legitimacy}

Those who hold political power listened to public opinion well before the invention of public opinion polls, but the manner in which public opinion is voiced has changed. The concept of public opinion appeared already in the eighteenth century, ${ }^{30}$ yet until the invention of scientific public opinion polls, no source of data could give direct, regular, and reliable measurements of public opinion, apart from elections. ${ }^{31}$ Between elections, the elected branches were perceived as the sole representation of public opinion. ${ }^{32}$ Moreover, before the introduction of opinion polling, "public opinion" was not understood as a simple aggregate of individual opinions but more as an "atmosphere" expressed by elites. ${ }^{33}$

Scientific public opinion polling was invented in the 1930s. ${ }^{34}$ After the Gallup organization accurately predicted Roosevelt's 1936 victory in the Presidential elections, based on a scientific sample (refuting a magazine's opposite prediction based on a non-scientific poll of more than two million mail ballots), the idea that a relatively small scientific sample of public opinion could accurately reflect the

30 See John Durham Peters, "Historical Tensions in the Concept of Public Opinion," in Theodore L. Glasser and Charles T. Salmon eds., Public Opinion and the Communication of Consent (New York: Guilford Press, 1995), 3, 14; John Durham Peters, "Realism in Social Representation and the Fate of the Public," in Slavko Splichal ed., Public Opinion and Democracy Vox Populi-Vox Dei? (Cresskill, NJ: Hampton Press, 2001), 85, 86.

${ }^{31}$ See Robert S. Erikson, Norman R. Luttbeg, and Kent L. Tedin, American Public Opinion: Its Origins, Content and Impact, 2nd ed. (New York: Wiley, 1980), 23.

${ }^{32}$ Amy Fried and Douglas B. Harris, "Governing with the Polls," The Historian 72 (2010), $321,323-24,353$.

${ }^{33}$ See Schmeller, "Imagining Public Opinion," 3, 11.

${ }^{34}$ See Peters, "Historical Tensions," 14. 
public opinion of the entire nation was established in the American public mind. ${ }^{35}$ Several decades of constant polling reshaped the term public opinion and it came to be synonymous with the results of opinion polls. ${ }^{36}$ Since the 1980 s, almost every public issue has been polled and the media devotes a great deal of attention to poll results. ${ }^{37}$ This public opinion culture made opinion polls in the public discourse an authoritative indicator of democratic legitimacy. ${ }^{38}$

Until the invention of public opinion polls, elected branches' attacks on the Court served as the major informative signal of the Court's waning public support. ${ }^{39}$ The elected representatives could always claim to hold public support for their position, and there was no accepted public indicator to refute their claim except on the rare occasions when the Court was an issue in national presidential campaigns. ${ }^{40}$ At that period, the view that the government as a whole requires public support (rather than individual institutions) was prevalent. ${ }^{41}$ "[A]11 government rest on opinion," wrote James Madison in The Federalist No. $49,{ }^{42}$ but the different branches of the regime do not require separate public support.

${ }^{35}$ See James S. Fishkin, The Voice of the People (New Haven, CT: Yale University Press, 1995), 77-8.

${ }^{36}$ George F. Bishop, The Illusion of Public Opinion (Lanham, MD: Rowman \& Littlefield 2005), 6; Susan Herbst, Numbered Voices: How Opinion Polling Has Shaped American Politics (Chicago, IL: University of Chicago Press, 1993), 63; Scott L. Althaus, Collective Preferences in Democratic Politics (Cambridge: Cambridge University Press, 2003), 5.

${ }^{37}$ See Bogart, Polls, 15, 21.

38 See Ackerman, The Decline, 75-6; Sarah E. Igo, The Averaged American (Cambridge, MA: Harvard University Press, 2007), 12-13, 18-19.

${ }^{39}$ See Jeffery Rosen, The Most Democratic Branch: How the Courts Serve America (Oxford: Oxford University Press, 2006), 9; Tom S. Clark, The Limits of Judicial Independence (New York: Cambridge University Press, 2011), 18-19, 193-94, 251-2, 256-7, 266-7.

40 See Larry D. Kramer, The People Themselves: Popular Constitutionalism and Judicial Review (New York: Oxford University Press, 2004), 189-90.

41 See Owen Fiss, "The Supreme Court, 1978 Term: Forward: The Forms of Justice," Harvard Law Review 93 (1979), 1, 38; Or Bassok, "The Supreme Court's New Source of Legitimacy," University of Pennsylvania Journal of Constitutional Law 16 (2013), 153, 160.

${ }^{42}$ The Federalist No. 49, 257 (James Madison). 
Gallup began conducting polls to measure public confidence in the Supreme Court as early as the late 1930s, yet it was not until the 1960s that the Gallup and Harris organization began to track public support for the Court and its decisions in any systematic way. ${ }^{43}$ The ability to track public support for the Court, the public record of this support (often published by popular media), and the scientific allure of opinion polls made public confidence in the Court more "real" in the public imagination. ${ }^{44}$ The entrance of public opinion polls as a reliable metric, measuring the confidence of the public in the Court and demonstrating it publicly, made it an independent criterion of legitimacy. ${ }^{45}$ It was now possible to view the Court's legitimacy in terms of public support for the first time in history.

True, long before the invention of public opinion polls, the Court already held that it "operates by its influence, by public confidence." 46 The Court was interested in public opinion throughout its history, but because of the lack of an accepted metric demonstrating public support for the Court, the elected representatives had a monopoly on the claim to legitimacy based on public support. ${ }^{47}$ Even if the Court was perceived at some historical periods as the people's delegate and the justices were seen as representatives of the people, ${ }^{48}$ in any confrontation with the elected branches no evidence could confirm the Court's claim to hold public support. Such claims to hold public confidence relied on impressionistic recollections of the public mood that were based on letters from the public, media coverage and so

43 See Thomas R. Marshall, Public Opinion and the Rehnquist Court (Albany, NY: State University of New York Press, 2008), 1-2, 29, 77; Gregory A. Caldeira, "Neither the Purse nor the Sword: Dynamics of Public Confidence in the Supreme Court," American Political Science Review 80 (1986), 1209, 1210-12.

${ }^{44}$ See Fried and Harris, "Governing with the Polls," 323.

${ }^{45}$ See Bogart, Polls, xxx.

${ }^{46}$ See Holmes, 618; United States v. Lee, 106 U.S. 196, 223 (1882).

${ }^{47}$ See Bassok, "The Supreme Court's New Source," 156.

${ }^{48}$ See for example, during the early days of the republic, Gordon S. Wood, The Creation of the American Republic, 1776-1787 (New York: Norton, 1972), 161. 
on. ${ }^{49}$ The Court could not rely on the tacit understanding, following published public opinion polls, that it enjoys higher levels of public support than elected branches. $^{50}$

Between elections, the job of elected representatives was, after all, representing public opinion and the climate of opinion they and the media created was understood to represent public opinion. ${ }^{51}$ The question is not only whether public representatives and the media presented an accurate picture of public opinion before the introduction of scientific polls, but also whether the Court's legitimacy could be understood by the Court and by the other branches as being based on public support. Public support for courts, with the exception of rare occasions when it is manifested in elections that are focused on court-related issues, is not by itself an exercise of power. People with power listen to it. ${ }^{52}$ Yet, in order for public opinion to be listened to, it needs to be measured or to be manifested through serious public mobilization. Thus, the Court does not need to state that it holds public support, but other institutions need to be aware of a reliable proof demonstrating public support for the Court.

It is hard to pinpoint the exact year in which the understanding of judicial legitimacy in terms of public support as expressed in opinion polls rose. In 1959, Joseph Menez, a political scientist, published an article titled "A Brief in Support

\footnotetext{
${ }^{49}$ See Jeff Shesol, Supreme Power: Franklin Roosevelt vs. the Supreme Court (New York: W.W. Norton, 2010), 305.

${ }^{50}$ See Ackerman, The Decline, 75. For the situation after the introduction of public opinion polls see Barry Friedman, The Will of the People: How Public Opinion Has Influenced the Supreme Court and Shaped the Meaning of the Constitution (New York: Farrar, Straus and Giroux, 2009), 15 ("In this course of acting thus, the Supreme Court has made itself one of the most popular institutions in American democracy. The Justices regularly outpoll the Congress and often even the President in terms of public support or confidence").

${ }^{51}$ Fried and Harris, "Governing with the Polls," 341.

52 Compare with Charles Taylor, A Secular Age (Cambridge, MA: Harvard University Press, 2007), 189-90.
} 
of the Supreme Court". ${ }^{53}$ Menez began his article by citing Hamilton's The Federalist No. 78, noting "[y]et [the Court's] judgment is precisely the factor which is the cause of the emotional, almost savage furor against it." ${ }^{" 54}$ At another point in his article he explains that

James Bryce saw the futility of popular elections. He perceived that the election of judges was an unwise extension of democracy for judges represent the law, not constituents. They are not delegates who are politically responsible. The Founding Fathers deliberately put the judiciary beyond the reach of the ballot box as well as the Gallup Poll. ${ }^{55}$

The judiciary today is no longer understood to be out of the reach of public opinion polls, which have become the official metric for public opinion. A sign for this change can be detected in John Hart Ely's 1977 Harvard Foreword. Ely attempts to show that even without the sword and the purse, the Court is quite powerful. He writes that while Hamilton's The Federalist No. 78 "must have made a good bit of sense at the outset of our nation. . . . Time has proven Hamilton's vision on this score badly mistaken." ${ }^{56}$ First, he argues that "formal checks," such as slashing the Court's budget, impeachment, packing the Court and constitutional amendment "have surely not proved to be of much consequence." ${ }^{57} \mathrm{He}$ then moves to discuss the fear that the Court will be destroyed by public backlash. Ely dismisses this fear noting that

53 Joseph F. Menez, "A Brief in Support of the Supreme Court," Northwestern University Law Review 54 (1959-1960), 30.

54 Ibid., 30.

${ }^{55}$ Ibid., 39.

56 John Hart Ely, "The Supreme Court, 1977 Term: Foreword: On Discovering Fundamental Values," Harvard Law Review 92 (1978), 5, 18-19.

${ }^{57}$ Ibid., 21 
[t]he warnings probably reached their peak during the Warren years; they were not notably heeded, yet nothing resembling destruction materialized. In fact the Court's power continued to grow, and probably has never been higher than it has been over the past two decades. ${ }^{58}$

In order to prove this last point Ely refers to three sources. ${ }^{59}$ The third is a news report on a "1977 Harris survey that ranked the Court high in public confidence."60 The two other sources are law review articles that offer an impressionistic assessment of "the prestige" 61 and "respect"62 of the Supreme Court. Both articles lack any reference to substantiate their assertions and both use tentative phrasing. The claims about public support for the Court are more claims about the public's mood than about public support in the aggregate form we are familiar with today. When reading these quotes one must bear in mind that they were written during a unique period in history; a period in which public opinion polls measuring support for the Court had already been introduced but their influence on public discourse had just begun.

During the same years Nathan Glazer wrote that

[i]n 1975, all evidence suggests that ... The courts truly have changed their role in American life. American courts . . . are now far more powerful than ever before; public opinion - which Tocqueville, Bryce and other analysts thought would control the courts as well as so much else in American life - is weaker. The legislatures and the executive now moderate their outbursts, for apparently outbursts will do no good. And courts, through interpretation of the Constitution and the laws, now reach into the

\footnotetext{
${ }^{58}$ Ibid.

${ }^{59}$ Ibid., n. 78.

${ }^{60}$ Ibid.

${ }^{61}$ Archibald Cox, "The New Dimensions of Constitutional Adjudication," Washington Law Review 51 (1976), 791, 826-7.

${ }^{62}$ Henry P. Monaghan, "The Supreme Court, 1974 Term: Foreword: Constitutional Common Law," Harvard Law Review 89 (1975), 1, 1-2.
} 
lives of the people, against the will of the people, deeper than they ever have in American history. ${ }^{63}$

The contrast between these three impressionistic assessments of the public attitude towards the Court offers a vivid example of why, in any conflict with the elected branches the Court was necessarily at a disadvantage in terms of claims of legitimacy on the basis of public support until the introduction of public opinion polls. Now compare these three quotes with a discussion in 2002 over the claim that the Court's legitimacy was undermined by the decision in Bush v. Gore. ${ }^{64}$ In response to this claim, Erwin Chemerinsky cites the results of a Gallup poll that proves that public confidence in the Court did not decline. This proves the point that the Court's legitimacy was not hindered and thus he immediately proceeds to offer explanations " $[\mathrm{w}]$ hy has there not been the loss in legitimacy that so many predicted on December 12." 65

The introduction of public opinion polls means that impressionistic assessments based on scholars' claims that the Court either has or lacks sociological legitimacy are now obsolete. Today, there is an agreed-upon metric. ${ }^{66}$ Moreover, public opinion polls measuring public support for the Court are on many occasions published in popular media thus providing public proof available to all of popular support for the Court. Subsequently, public support for the Court or the lack of it is now considered as a fact and the other branches of government cannot easily dispose of it by arguing that they better represent public opinion towards the Court.

Within several years of its introduction, this new metric, offering a straightforward mechanism to measure public attitudes toward the Court, made

${ }^{63}$ Nathan Glazer, “Towards an Imperial Judiciary?," The Public Interest (1975), 104, 106.

${ }^{64}$ Erwin Chemerinsky, How Should We Think About Bush v. Gore?, Loyola University Chicago Law Journal 34 (2002).

${ }^{65}$ Ibid., 3.

${ }^{66}$ See Bogart, Polls, x, 5 
prevalent in the American discourse the idea that the Court's legitimacy is to be understood in terms of public support, as measured in opinion polls. Scholars continuously argue that "judicial power ultimately depended upon popular acceptance" $" 67$ or that "the Court must take care to behave in a way that inspires or maintains public confidence." ${ }^{68}$ Rather than emphasizing the difference between the Court's source of legitimacy and that of the elected branches, it is now common to argue that "[1]ike the executive and legislative branches, the judiciary depends on public support for its legitimacy." 69

In 2009 Barry Friedman wrote an excellent book titled The Will of the People: How Public Opinion Has Influenced the Supreme Court and Shaped the Meaning of the Constitution, which retells the entire history of the Supreme Court on the premise that in order to function properly the Court requires public support. ${ }^{70}$ In essence, according to Friedman's account, judicial legitimacy has always been understood in terms of public opinion: the only change is that, with time, the justices have become better at assessing and maintaining public support. ${ }^{71}$ While public opinion has undoubtedly affected the Court throughout its entire history, the introduction of public opinion polls changed the rules of the game with the creation of a new understanding of judicial legitimacy. ${ }^{72}$

\footnotetext{
${ }^{67}$ Friedman, The Will, 221.

${ }^{68}$ Michael L. Wells, “'Sociological Legitimacy' in Supreme Court Opinions," Washington \& Lee Law Review 64 (2007), 1011, 1016.

${ }^{69}$ Benjamin J. Roesch, "Crowd Control: The Majoritarian Court and the Reflection of Public Opinion in Doctrine," Suffolk University Law Review 39 (2006), 379. See also David B. Rottman and Alan J. Tomkins, "Public Trust and Confidence in the Courts: What Public Opinion Surveys Mean to Judges," Court Review 36 (1999), 24.

${ }^{70}$ Friedman, The Will.

${ }^{71}$ Ibid., 376.

${ }^{72}$ Friedman notes that a change did occur in the Court's adjudication around the time of the introduction of public opinion polls, but cannot put the finger on the cause of this change. See Friedman, The Will, 4 ("the Supreme Court went from being an institution intended to check the popular will to one that frequently confirms it."). For my critique of this account see Bassok, "The Supreme Court's New Source," 192-3.
} 
In his book, Making Our Democracy Work - A Judge's View, Justice Stephen Breyer writes that "[t]he Court itself must help maintain the public's trust in the Court" in order to ensure its proper function. ${ }^{73}$ Referring to Breyer and Friedman's books, scholars Laurence Tribe and Joshua Matz state in their 2014 book that "[1]ike any branch of government, the Court cares deeply about its legitimacy and its role in our democratic society." 74 They do not feel the need to note explicitly that by relying on these sources they are referring to legitimacy in the sociological sense rather than legitimacy in its normative sense. This meaning is now the commonsensical or the natural one.

The availability of this new way to understand judicial legitimacy has affected the behavior of representative branches towards the Court as well as the Court's understanding of itself. First, there was a shift in the institutional dynamics between the branches of government. The political branches may now enforce the Court's decisions not as a result of its expertise - as if they were the patient doing as the doctor ordered - but because of public support for the Court. ${ }^{75}$ After all, between elections, this is the regular pattern of behavior of political players towards each other. ${ }^{76}$ Even when the Court is perceived to act politically that is, not according to its expertise, as long as it holds public confidence, political resistance to its decisions seems unfeasible. Public opinion is the driving wheel of American politics, and no politician wants to stand against it. ${ }^{77}$

${ }^{73}$ Stephen Breyer, Making Our Democracy Work: a Judge's View (New York: Alfred A. Knopf, 2010), xiii.

74 Laurence Tribe and Joshua Matz, Uncertain Justice: The Roberts Court and the Constitution (New York: Henry Holt, 2014), 5.

${ }^{75}$ Bassok, "The Supreme Court's New Source," 165-6.

${ }^{76}$ See Clark, The Limits of Judicial Independence, 81-2.

77 James A. Stimson, Tides of Consent (Cambridge: Cambridge University Press, 2004), xvxvii. 
Second, justices, both conservatives and progressives, have adopted the idea that the Court's legitimacy relies on public confidence. ${ }^{78}$ In other words, the justices themselves now understand the Court's legitimacy in sociological terms more than ever before.

Table 1. Understanding Judicial Legitimacy before and after the Introduction of Public Opinion Polls

\begin{tabular}{|c|c|c|}
\hline & $\begin{array}{l}\text { Why do other branches } \\
\text { obey the Court? }\end{array}$ & $\begin{array}{l}\text { In what terms is judicial } \\
\text { legitimacy mainly } \\
\text { understood? }\end{array}$ \\
\hline $\begin{array}{l}\text { Judicial legitimacy } \\
\text { according to Hamilton }\end{array}$ & Judicial expertise & Normative \\
\hline $\begin{array}{l}\text { Revisionist understanding } \\
\text { of judicial legitimacy }\end{array}$ & $\begin{array}{l}\text { Public support (as } \\
\text { measured in public } \\
\text { opinion polls) }\end{array}$ & Sociological \\
\hline
\end{tabular}

Table 1 summarizes the influence of the introduction of public opinion polls. ${ }^{79}$ It is important to stress that I do not argue that after the introduction of opinion polls the normative understanding of judicial legitimacy disappeared. Many today

${ }^{78}$ See, e.g., Planned Parenthood v. Casey, 505 U.S. 833, 865 (1992) (plurality opinion): "The Court's power lies, rather, in its legitimacy, a product of substance and perception that shows itself in the people's acceptance of the Judiciary..."; Republican Party of Minnesota v. White, 536 U.S. 765, 817-18 (2002) (Stevens, J., dissenting); See also Sandra Day O'Connor, "Public Trust as a Dimension of Equal Justice: Some Suggestions to Increase Public Trust," Court Review 36 (1999), $10,13$.

${ }^{79}$ The table is simplified because the shift from expertise to public support is related not only to the introduction of opinion polls but also to the decline of belief in judicial expertise. See infra section 3 . 
continue to discuss the Court's legitimacy in normative terms. ${ }^{80}$ Nor do I deny that in the past the Court's legitimacy was discussed also in sociological terms. Rather, I argue that with the introduction of public opinion polls, a new understanding has become available and prevalent.

Understanding the Court's legitimacy in terms of enduring public support does not mean that the Court has to follow public opinion. Courts can recruit public support in various ways. ${ }^{81}$ For example, there is empirical evidence demonstrating that Americans support originalism as a method of interpretation. ${ }^{82}$ Subsequently, a court that adheres to originalism as an interpretative method may enjoy enduring public support even if it decides against public opinion.

In his recent dissenting opinion in Obergefell, Chief Justice Roberts notes that "[t]he legitimacy of this Court ultimately rests 'upon the respect accorded to its judgments.' Republican Party of Minn. v. White, 536 U. S. 765, 793 (2002) (Kennedy, J., concurring)." ${ }^{83}$ Like most American jurists of this generation, Roberts adheres to the idea that judicial legitimacy is to be understood in terms of public support. ${ }^{84}$ Yet he continues and explains that legitimacy "flows from the perception - and reality - that we exercise humility and restraint in deciding cases according to the Constitution and law." 85 In other words, public support comes from the Court's adherence to what I called in a previous article: "thin

\footnotetext{
${ }^{80}$ See for example, Jeremy Waldron, "The Core of the Case against Judicial Review," Yale Law Journal 115 (2006), 346.

${ }^{81}$ Bassok, "The Supreme Court's New Source," 183, 195.

82 See for example, Jamal Greene, "Selling Originalism," Georgetown Law Journal 97 (2009), 661, 695; Jamal Greene, Nathaniel Persily and Stephen Ansolabehere, "Profiling Originalism," Columbia Law Review 111 (2011), 356, 367.

${ }^{83}$ Obergefell, 2624.

${ }^{84}$ See for example, Jeffrey Rosen, "Are Liberals Trying to Intimidate John Roberts?," The New Republic, May 28, 2012.

${ }^{85}$ Obergefell v. Hodges, 756 U.S.
} 
expertise." ${ }^{86}$ Roberts' approach was best captured by his use of the umpire metaphor during his confirmation hearings. ${ }^{87}$ As he then explained, " $[\mathrm{u}]$ mpires don't make the rules, they apply them." $" 88$

In the second paragraph of his dissenting opinion in Obergefell v. Hodges, Chief Justice Roberts stresses that " $[\mathrm{u}]$ nder the Constitution, judges have power to say what the law is, not what it should be." ${ }^{89}$ He then quotes The Federalist No. 78 in its correct "judgment" form (rather than paraphrasing it). He further writes that "[t]he majority's decision is an act of will, not legal judgment." ${ }^{\text {90 }}$ Roberts is thus a good example of a justice who adheres to the understanding of judicial legitimacy based on public support and yet states that such support is gained through exhibiting legal judgment and not by following public opinion. Roberts gives expression to this view at the end of his dissenting opinion writing that "the legitimacy of [the judges'] power depends on confining it to the exercise of legal judgment." 91

\section{Can Constitutional Doctors Exist?}

Today, Hamilton's line of thinking, according to which the Court's legitimacy is based on its expertise, may sound naive to American ears. Perhaps that is why Karlan was convinced he was "slightly off". Ever since the clash between President Franklin D. Roosevelt and the Court over New Deal legislation,

\footnotetext{
${ }^{86}$ See Or Bassok, "The Court Cannot Hold," Journal of Law \& Politics 30 (2014), 1, 38, 413. See also, Neil S. Siegel, "Umpires at Bat: On Integration and Legitimation," Constitutional Commentary 24 (2007), 701, 724-6.

${ }^{87}$ See Charles Fried, "Balls and Strikes,” Emory Law Journal 61 (2012), 641, 644-5.

${ }^{88}$ Confirmation Hearing on the Nomination of John G. Roberts, Jr. to be Chief Justice of the United States before the S. Comm. on the Judiciary, 109th Cong. 55 (2005) (statement of Judge John G. Roberts, Jr.).

${ }^{89}$ Obergefell v. Hodges, 756 U.S.2611.

${ }^{90}$ Ibid.

${ }^{91}$ Ibid.
} 
increased public awareness of the indeterminacy of constitutional norms has undermined the public's belief in the Court's legal expertise. ${ }^{92}$ Since the 1930s, the public has come to understand that in constitutional cases there is an element of choice that cannot be dictated by legal expertise and that the law's malleability allows for political influence over judicial discretion. ${ }^{93}$ This "discovery" of broad judicial discretion in constitutional cases has eroded the public belief that the justices hold professional legal expertise that enables them to arrive at the correct legal answer. ${ }^{94}$ The media constantly frame the Court's judgments as not dictated by the law but influenced by the justices' political alignment. ${ }^{95}$ It is no surprise, then, that the public has come more and more to perceive the Court in recent decades as deciding salient cases not solely based on the law, but also according to the justices' own political preferences. ${ }^{96}$ This evolution in how the American public imagines the Court touched the very core of the justices' claim to legitimacy based on legal expertise.

But what seems naive to Americans regarding the Supreme Court does not seem so to them with regard to the Federal Reserve Bank (hereinafter: the Federal Bank). The Federal Bank was designed as an institution that offers judgments in its realm of expertise and is unaccountable to the public. ${ }^{97}$ At least until recently, it was almost undisputed for many decades that the executive complies with the Federal Bank's judgments because of its expertise and not because it holds popular

${ }^{92}$ See for example, Bassok, "The Sociological-Legitimacy Difficulty," 250-1.

${ }^{93}$ See Friedman, The Will, 214-15.

${ }^{94}$ See for example, John Hart Ely, Democracy and Distrust (Cambridge, MA: Harvard University Press, 1980), 44

${ }^{95}$ RonNell Andersen Jones, "Media Politicization of the United States Supreme Court," Oñati Socio-legal Series 4 (2014), 613.

${ }^{96}$ See Charles Gardner Geyh, "Can the Rule of Law Survive Judicial Politics," Cornell Law Review 97 (2012), 191, 222.

97 John T. Woolley, Monetary Politics: The Federal Reserve and the Politics of Monetary Policy (Cambridge: Cambridge University Press, 1986), 88. 
support. ${ }^{98}$ Why is the American Supreme Court different? What comes to mind immediately is that non-compliance with the Federal Reserve's judgment is like refusing to adhere to a doctor's medical advice. ${ }^{99}$ But judges seem to be perceived differently from economists. At least with regard to salient constitutional cases, such as those dealing with the constitutionality of the death penalty, the American public's belief that the justices possess any relevant expertise to decide these questions has substantially weakened. ${ }^{100}$ The Federal Bank and its decisions that influence the interest rates are regarded differently. This difference in how Americans imagine these two institutions is a result of contingent historical developments. Economics is still considered in the USA to be a form of expertise to which a separate section is dedicated in newspapers (as opposed to legal issues that appear in the general news section). However, after the economic crisis of 2008 , one can easily see beyond this horizon and imagine a world in which the salient decisions of the Federal Bank are considered to be as political as the Court's decisions. ${ }^{101}$ Such a reality existed during the founding era and up to the 1850s, when economics was not understood as field that can be understood according to an autonomous expertise, but as a field that mirrors politics and public opinion. ${ }^{102}$ As Mark Schmeller explains, at that period

98 Ibid., 57, 88.

${ }^{99}$ See Frederick Schauer, "The Supreme Court, 2005 Term: Foreword: The Court's Agenda — and the Nation's," Harvard Law Review 120 (2006), 4, 54-5.

100 See Suzanna Sherry, "Democracy's Distrust," Harvard Law Review Forum 125 (2011), 7, 11.

101 See Richard Bellamy, Political Constitutionalism (Cambridge: Cambridge University Press, 2007), 169.

102 See Schmeller, "Imagining Public Opinion," 89-99, 142-50; Michael J. Sandel, Democracy's Discontent: America in Search of a Public Philosophy (Cambridge, MA: Harvard University Press, 1996), 137-9, 192-7, 274-5. 
the causes of economic panics were explained in terms of public opinion. After all, antebellum Americans had no theories of business cycles on hand to explain why good times suddenly turned hard. ${ }^{103}$

The contingent nature of current American disbelief in legal expertise becomes evident after reading Theunis Roux's book on the success of the SACC in its first decade of existence. ${ }^{104}$ As Roux admits, measured by standards of normative legitimacy and expertise, the story of SACC in its first 10 years of existence is one of great success. However, Roux himself does not view the first 10 years of the Court as a complete success since "the Court never built the kind of public support that is ordinarily taken to be the mark of a successful constitutional court."105 Roux's book demonstrates that an attempt to apply the new understanding of the concept of judicial legitimacy; an understanding created in the American context, fails in the South African context. The relevant players still viewed the SACC as an expert. Allow me to elaborate on this example. ${ }^{106}$

From the outset of his book it is clear that Roux adopted the understanding of judicial legitimacy that originates in American constitutional thought according to which, in order to function properly, a court must have enduring public support, that is, sociological legitimacy. Roux writes that "a certain level of public support is a precondition for whatever else a constitutional court may hope to achieve."107 The method of assessing public support, along this line of thinking, is polling public opinion. In other words, in order to function properly, the SACC needed to hold enduring public support as measured in opinion polls.

\footnotetext{
${ }^{103}$ See Schmeller, "Imagining Public Opinion," 149.

104 Theunis Roux, The Politics of Principle: The First South African Constitutional Court, 1995-2005 (Cambridge: Cambridge University Press, 2013), 391.

105 Ibid.

106 See also Or Bassok, "South African Constitutional Doctors with No Public Support," Constitutional Commentary 30 (2015), 101.

${ }^{107}$ Roux, The Politics, 37.
} 
Yet, Roux encountered a problem: the SACC functioned properly without possessing enduring public support. Roux could not deny that "the South African case appears to defy this rule." 108 Surveys conducted by James Gibson and Gregory Caldeira in 1996-1997, 2001 and 2004 showed that the Court never built enduring public support. ${ }^{109}$ These "brute facts about the Chaskalson Court's institutional legitimacy" 110 meant that if courts' legitimacy is determined in sociological terms, the SACC lacked legitimacy. And yet, Roux writes that

the interesting thing about the Chaskalson Court is that it was able to play its constitutionally assigned veto role from the very outset, and that it continued to play this role without ever building much institutional legitimacy. ${ }^{111}$

While Roux attempts to explain the SACC's success without abandoning the notion that the courts' legitimacy is measured by the level of enduring public support, the account he gives in his book supports Hamilton's line of thinking. In Roux's narrative the South Africans elite, which consisted mostly of the African National Congress party (ANC), believed in judicial expertise even in salient and controversial constitutional questions. ${ }^{112}$ Some of the ANC's leaders, and in particular Nelson Mandela, complied with the SACC's decisions simply because they believed in its expertise even when the SACC ruled against their interests. ${ }^{113}$ Even with rifts inside the ANC during the Mbeki presidency, and the ensuing decline of strategic reasons by part of the ANC leadership to support the Court, "very few attacks on the Court were in fact launched, and none that could be

\footnotetext{
108 Ibid., 37.

109 Ibid., 37.

${ }^{110}$ Ibid., 34.

${ }^{111}$ Ibid., 4, 8, 15, 37-8, 206-7.

112 Ibid., 3, 112, 213, 219, 382.

113 Ibid., 127, 173, 189.
} 
described as successful." "114 The belief in the SACC's expertise was not necessarily a belief only in judicial expertise in legal doctrine (though that existed as well. ${ }^{115}$ ). Rather, as Roux explains, the ANC obeyed the Court during the Chaskalson era out of a commitment to human rights and because the Court was perceived as an expert in human rights. ${ }^{116}$

The success of the SACC in the first 10 years of its existence is explained better by Hamilton's understanding of the judiciary's basis of legitimacy than by the current revisionist understanding. As Roux himself admits:

[T]he Court was continually able to defy the ordinary assumptions of liberal constitutional theory by exploiting the ANC's dominance to carve out a role for itself as an independent check on the abuse of political power. ${ }^{117}$

As long as the executive branch is persuaded by the expertise of the national high court and the system of governance as a whole possesses public confidence, public support for the national high court as a distinct institution is not crucial for its proper function. Understanding the concept of legitimacy in the way that Hamilton did in The Federalist No. 78 is not a form of naivety.

\section{From Public Deference to Public Acknowledgment to Public Confidence}

In Baker v. Carr ${ }^{118}$ the Court held that voters whose franchise is diluted by the discriminatory apportionment of legislative seats may seek relief in federal courts

${ }^{114}$ Ibid., 186-7, but see 8.

115 Theunis Roux, "Principle and Pragmatism on the Constitutional Court of South Africa," International Journal of Constitutional Law 7 (2009), 106, 138.

${ }^{116}$ Roux, The Politics, 388.

117 Ibid., 363.

118 Baker v. Carr 369 U.S. 186. 
rather than be rejected based on justiciability grounds. This was the first time the Court held that legislative districting presented a justiciable controversy. ${ }^{119}$ Baker v. Carr was the first step in the Court's attempt to eliminate population inequalities in political representation and to truly fulfill the promise of "one person, one vote." 120 Justice Frankfurter's dissenting opinion offers an argument about the proper role of the judiciary in the political process. In his view, courts do not offer solutions to the ills of population inequality in the context of political representation. He concluded that the case posed a political question and was thus nonjusticiable, and that the public should rely on their representatives to provide relief. ${ }^{121}$ Frankfurter puts special emphasis on the concern that judicial supervision of democratic politics would hinder the Court's legitimacy. ${ }^{122}$ My focus here is only on Frankfurter's vision of judicial legitimacy which is the basis of his analysis.

Frankfurter describes the Court's source of legitimacy in the following words: "The Court's authority — possessed of neither the purse nor the sword ultimately rests on sustained public confidence in its moral sanction." 123

Researching earlier drafts of this opinion brings to light two other versions Frankfurter considered. (I have marked the changes between the two versions of the sentence appearing in the drafts and the final version in italics.) The first version of this sentence appears in a 1962 January draft: "The Court's power

\footnotetext{
119 Sanford Levinson, “One Person, One Vote: A Mantra in Need of Meaning,” North Carolina Law Review 80 (2002), 1269, 1269.

120 James A. Gardner, "One Person, One Vote and the Possibility of Political Community," North Carolina Law Review 80 (2002), 1237, 1237.

${ }^{121}$ Baker v. Carr 369 U.S. 186, 269-70. See also Guy-Uriel E. Charles, "Constitutional Pluralism and Democractic Politics: Reflections on the Interpretive Approach of Baker v. Carr," North Carolina Law Review 80 (2002), 1103, 1109.

${ }_{122}$ Charles, Constitutional Pluralism, 1109.

${ }^{123}$ Baker v. Carr 369 U.S. 186, 267.
} 
ultimately rests in sustained public deference to its moral authority. ${ }^{124}$ On a draft dated February 1962, this sentence was changed and the second version reads: "The Court's power - possessed neither of the purse nor the sword - ultimately rests on sustained public acknowledgment of its moral authority." 125

The implied reference to The Federalist No. 78 in adding "the purse" and "the sword," and the replacement of "deference" with "acknowledgement" were made together in handwriting in the margins of the printed text of the February draft. Although he does not explicitly refer to The Federalist No. 78 (as he does at other points in his opinion when he refers to The Federalist No. 54, 56 and $62^{126}$ ) it is hard to imagine that when he inserted the reference to the sword and the purse, Frankfurter was unaware that he was paraphrasing Hamilton. Frankfurter referred to The Federalist Papers as "a lawyer's brief by the framers of the Constitution in support of their handiwork," 127 and was second in the Court only to Justice Douglas in the amount of explicit references he made in his opinions to The Federalist Papers. ${ }^{128}$

While only the second version of this sentence clearly resembles The Federalist No. 78, in all of the versions the idea that the Court's power or authority ultimately rests on the public, rather than on judgment, remains constant. However, the public's required state of mind changes from "deference" to "acknowledgment" to "confidence." The trend is clear - the level of required public affinity for the Court increases. It is not enough for the public to merely acquiesce to the Court's

124 Felix Frankfurter, Draft Baker Dissent, January, 1962, at 5. (available at The Felix Frankfurter Papers, Part II, ProQuest electronic database).

${ }^{125}$ Felix Frankfurter, Draft Baker Dissent, February, 1962, at 5.

${ }^{126}$ Baker v. Carr 369 U.S. 186, 303 and n. 62, 308-309 and n. 62, 74, 75.

127 William O. Douglas, "The Lawyer and the Public Service," American Bar Association Journal 26 (1940), 633, 635 (quoting Justice Frankfurter).

128 James G. Wilson, "The Most Sacred Text: The Supreme Court's Use of The Federalist Papers," Brigham Young University Law Review (1985), 65, 66 and n. 5. 
moral authority, nor is it enough that it would recognize the Court's moral authority. The public needs to trust the Court's moral sanction.

Baker v. Carr was not the first time Frankfurter spoke of the Court's authority as being dependent on public confidence. ${ }^{129}$ Yet we should refrain from anachronism. In many current public opinion polls the measure of public support for the Court is public confidence. ${ }^{130}$ However, in 1962, public opinion polls had just begun to make their mark on the understanding of the Court's source of legitimacy. For example, Frankfurter's former clerk Alexander Bickel wrote in his 1962 book The Least Dangerous Branch, ${ }^{131}$ "[m]ost assuredly, no democracy operates by taking continuous nose counts on the broad range of daily governmental activities." 132 As this quote shows, Bickel was not oblivious to the new polling technology. Yet he still did not fully realize its effects on the Court when he formulated the counter-majoritarian difficulty as the problem of an unaccountable Court rather than the difficulty of a judicial institution that is unresponsive to public opinion as expressed in opinion polls. ${ }^{133}$

The meaning of public opinion for Frankfurter was very different than ours. Public opinion was not yet synonymous with public opinion polls since public opinion polls had yet to acquire their current status. ${ }^{134}$ Frankfurter was well aware

${ }^{129}$ See Felix Frankfurter, "Hours of Labor and Realism in Constitutional Law," Harvard Law Review 29 (1916), 353, 371; Felix Frankfurter, "The United States Supreme Court Molding the Constitution," Current History 32 (1930) 235; Felix Frankfurter, "The Judicial Process and the Supreme Court," in Of Law and Men: Papers and Addresses of Felix Frankfurter, 1939-1956, ed. Philip Elman (New York: Harcourt, Brace and company, 1956), 31.

${ }^{130}$ For example, Robert H. Durr, Andrew D. Martin and Christina Wolbrecht, "Ideological Divergence and Public Support for the Supreme Court," American Journal of Political Science 44 (2000), 768, 768-9.

131 Alexander M. Bickel, The Least Dangerous Branch: The Supreme Court at the Bar of Politics (Indianapolis, IN: Bobbs-Merrill, 1962).

132 Ibid., 17.

${ }^{133}$ See Or Bassok, “The Two Countermajoritarian Difficulties," Saint Louis University Public Law Review 32 (2012), 333, 337-9.

${ }^{134}$ See Bogart, Polls, 14. 
of the development of opinion polling. For example, in his correspondence with Walter Lippmann, who wrote several important books on public opinion, Frankfurter spoke of "polls mischief" and regarded the idea of forming public policy by consulting Gallup polls as a great mistake. ${ }^{135}$ In the context of judicial legitimacy, polls measuring public support for the Court were not yet frequent. For these reasons, it is a misreading to understand the sentence in Baker v. Carr as suggesting that, even without the sword or the purse, the Court can stand on its own feet facing the other branches of government based on its public support as measured in public opinion polls. Frankfurter's dissenting opinion, let us not forget, calls for a retreat of the Court from the political domain.

For Frankfurter public opinion was more an atmosphere created by the media and not a simple aggregate of individual opinions. ${ }^{136}$ His close friend, Walter Lippmann expressed this understanding when he described public opinion as a "phantom" of the media or elite opinion, projected in order to legitimatize the views of the elite. ${ }^{137}$ Frankfurter envisioned a tripartite structure of American society in which experts communicate their knowledge to the elite that is charged with educating the mass public. ${ }^{138}$ Legal historian Brad Snyder explains that Frankfurter shared "Jefferson's faith in the democratic political process and enlightened public opinion." 139 Throughout his article, Snyder continues to use the term "enlightened public opinion" when he discusses Frankfurter's views. ${ }^{140} \mathrm{He}$ notes that "The Flag Salute Cases, Brown and its progeny, and Baker v. Carr

135 Craufurd D. Goodwin, Walter Lippmann: Public Economist (Cambridge, MA: Harvard University Press, 2014), 358.

${ }^{136}$ Cf. Schmeller, "Imagining Public Opinion," 168-69.

${ }^{137}$ See Walter Lippmann, The Phantom Public (New York: Harcourt, Brace, 1927).

138 Sanford Levinson, “The Democratic Faith of Felix Frankfurter," Stanford Law Review 25 (1973), 430, 440-1.

${ }^{139}$ See Brad Snyder, "Frankfurter and Popular Constitutionalism," UC Davis Law Review 45 (2013), 343, 343 (my emphasis), 345.

140 Ibid., 368. 
highlight Frankfurter's Jeffersonian faith in enlightened public opinion." ${ }^{141}$ Since Frankfurter attributed to the concept of public opinion a meaning that is different from the one we currently attribute to it, adding the term enlightened is required in order to avoid anachronism.

Only by viewing public opinion as enlightened public opinion can we reconcile Frankfurter's strong belief in expertise with his strong belief in democracy. ${ }^{142}$ Frankfurter never believed that the Court, an expert in law, should follow public opinion. In his dissent in West Virginia State Bd. of Educ. v. Barnette (1943) he emphasized that " $[\mathrm{t}]$ he Court has no reason for existence if it merely reflects the pressures of the day"143 and in Dennis v. U.S. (1951) Frankfurter stressed that "[c]ourts are not representative bodies. They are not designed to be a good reflex of a democratic society." 144 Yet, although Frankfurter was a great believer in legal expertise, ${ }^{145}$ he did not support justices weighing in on every public issue. There are other experts in other fields and besides, the final word belongs to the enlightened public. The Court as an expert needs to "be on tap, but never on top." $" 146$

${ }^{141}$ Ibid., 351, 415.

${ }^{142}$ Levinson, "The Democratic Faith," 432-3; see also 439-40.

${ }^{143}$ West Virginia State Bd. of Educ. v. Barnette, 319 U.S. 624, 665 (1943).

144 Dennis v. U.S., 341 U.S. 494, 525 (Frankfurter, J, concurring).

145 Michael E. Parrish, "Felix Frankfurter, The Progressive Tradition, and the Warren Court," in The Warren Court in Historical and Political Perspective, ed. Mark Tushnet (Charlottesville, VA: University Press of Virginia, 1993), 51, 61.

146 Felix Frankfurter, The Public and its Government (New Haven, CT: Yale University Press, 1930), 164. See also Parrish, "Felix Frankfurter," 59. 
Table 2. Frankfurter's View on Judicial Legitimacy

\begin{tabular}{|l|l|l|}
\hline & $\begin{array}{l}\text { Why do other branches } \\
\text { obey the Court? }\end{array}$ & $\begin{array}{l}\text { In what terms is judicial } \\
\text { legitimacy mainly } \\
\text { understood? }\end{array}$ \\
\hline Frankfurter's position & $\begin{array}{l}\text { Enlightened public } \\
\text { confidence }\end{array}$ & Normative \\
\hline
\end{tabular}

In comparison to Frankfurter's quotes cited above, in Baker v. Carr Frankfurter adds a twist: the confidence is in the Court's "moral sanction." Frankfurter's sentence presents the idea that the Court would receive the confidence of the enlightened public as long as its authority enjoyed moral justification. In Table 1 presented earlier, Frankfurter's position is an intermediate one (see Table 2).

According to Frankfurter's view, an argument that has normative legitimacy will necessarily gain the support of the enlightened public. In his tripartite structure, the elite would necessarily be convinced by the expert who presents valid arguments, and the mass public would be educated to support the correct position.

\section{Conclusion}

The concept of judicial legitimacy has been changing. It is not easy to detect the change since the names of the concepts we are using - legitimacy, public opinion - have remained the same. As I have shown, one way to detect the change is by following how The Federalist No. 78 is paraphrased by contemporary jurists, usually without the jurist even noticing the change in its meaning. 
Our understanding of basic concepts such as legitimacy usually changes very slowly. Relatively rapid shifts sometimes occur as the result of a technological innovation. Since technological innovation destabilizes the social context in which language acquires meaning, concepts used in technological environments different from our own may have drastically different meanings. Take, for example, the shift in how we understand the word "smart" today in comparison to Biblical times. ${ }^{147}$ The Bible tells us that King Solomon was considered the smartest of all people, because (among other things) "he uttered 3,000 proverbs."148 This was how an oral society, in which memory had the utmost importance, imagined what it meant to be smart. Today, with internet sites holding tens of thousands of proverbs, a man like Solomon, who offers a proverb for every situation, would surely not be considered the smartest of all. The meaning of the word smart was altered as a result of technological innovations.

The introduction of public opinion polls had a similar effect. In the USA, the understanding of public opinion is currently so inseparable from the results of public opinion polls that the idea of sociological legitimacy has become synonymous with public support as manifested in public opinion polls. ${ }^{149}$ Furthermore, I have shown that in recent decades the availability of opinion polls measuring public support for the Court, together with the dominance of the public opinion culture and the decline in the belief in legal expertise have made this form of legitimacy more prevalent in understanding the concept of judicial legitimacy.

Chief Justice Roberts' reliance in Obergefell v. Hodges on The Federalist No. 78 famous dictum on judicial legitimacy and his use of Justice Kennedy's paraphrase of the same dictum demonstrate how this basic issue is still at the center of the Court's adjudication. And yet, with all the focus on this topic, the change in

\footnotetext{
${ }^{147}$ See Neil Postman, Amusing Ourselves to Death (New York: Penguin Books, 1986), 25.

1481 Kings 5:10-12.

${ }^{149}$ See Bogart, Polls, xxix.
} 
understanding the concept of judicial legitimacy resulting from the introduction of public opinion polls has been concealed from our eyes. 